\title{
Variation in the Care of Acute Liver Failure: A Survey of Intensive Care Professionals
}

\author{
Filipe S. Cardoso $^{\text {a }}$ Mark J. Mcphail $^{\text {b }}$ Constantine J. Karvellas ${ }^{c}$ \\ Valentin Fuhrmann $^{d}$ Nuno Germano ${ }^{a}$ Georg Auzinger ${ }^{b}$

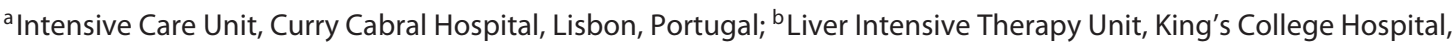 \\ London, UK; ' ${ }^{C}$ Department of Critical Care Medicine, University of Alberta, Edmonton, AB, Canada; ${ }^{d}$ Department of \\ Medicine B, Gastroenterology and Hepatology, University of Münster, Münster, Germany
}

\section{Keywords}

Hepatitis · Critical care · Outcomes · Survey

\section{Abstract}

Introduction: Acute liver failure (ALF) is a rare disease with potentially high mortality. We sought to assess the individual approach to ALF by intensive care unit (ICU) professionals. Methods: Cross-sectional survey of ICU professionals. Webbased survey capturing data on respondents' demographics, characteristics of patients with ALF admitted to ICU, and their management. Results: Among 204 participants from 50 countries, 140 (68.6\%) worked in Europe, 146 (71.6\%) were intensivists, $142(69.6 \%)$ admitted $<25$ patients with ALF per year, and $166(81.8 \%$ ) reported $<25 \%$ of patients had paracetamol-related ALF. On patients' outcomes, 126 (75.0\%) reported an emergency liver transplantation (ELT) rate $<25 \%$ and $140(73.3 \%)$ a hospital mortality rate $<50 \%$. The approach to ALF in the ICU varied with age, region, level of training, type of hospital, and etiology (prescribing $\mathrm{N}$-acetylcysteine for paracetamol toxicity, triggers for endotracheal intubation, measurement of and strategies for lowering serum ammonia, extracorporeal device deployment, and prophylactic antibiotics). Conclusions: The management of patients with ALF by ICU professionals differed substantially concerning the relevant clinical measures taken. Further education and high-quality research are warranted.

(c) 2021 Sociedade Portuguesa de Gastrenterologia Published by S. Karger AG, Basel

Variação nos cuidados da falência hepatica aguda: um inquérito a profissionais de cuidados intensivos

Palavras-Chave

Hepatite · Cuidados críticos · Resultados · Inquérito

\section{Resumo}

Introdução: A falência hepatica aguda (ALF) é uma doença rara potencialmente letal. Pretendeu-se avaliar a abordagem individual à ALF por profissionais da Unidade de Cuidados Intensivos (UCI). Métodos: Inquérito transversal de profissionais da UCI. Inquérito online capturando informação da demografia dos respondedores, características dos doentes com ALF admitidos na UCl e sua abordagem. Resultados: Entre 204 participantes de 50 países, 140 (68.6\%) trabalhavam na Europa, 146 (71.6\%) eram inten- karger@karger.com www.karger.com/pjg

Karger $\stackrel{\text { ' }}{5}$

BOPEN ACCESS (c) 2021 Sociedade Portuguesa de Gastrenterologia Published by S. Karger AG, Basel

This is an Open Access article licensed under the Creative Commons Attribution-NonCommercial-4.0 International License (CC BY-NC) (http://www.karger.com/Services/OpenAccessLicense), applicable to the online version of the article only. Usage and distribution for commercial purposes requires written permission.
Correspondence to:

Filipe S. Cardoso, filipe_sousacardoso@ hotmail.com 
sivistas, 142 (62.9\%) admitiam <25 doentes com ALF por ano, e $166(81.8 \%)$ reportaram $<25 \%$ dos doentes com ALF relacionada com paracetamol. Quanto aos resultados dos doentes, $126(75.0 \%)$ reportaram uma taxa de transplantação hepatica emergente (ELT) <25\% e 140 (73.3\%) uma taxa de mortalidade hospitalar $<50 \%$. A abordagem da ALF variou com a idade, região, nível de treino, tipo de hospital, ou etiologia nos seguintes tópicos: prescrição de $\mathrm{N}$-acetil-cisteína, critérios de intubação orotraqueal, medição e estratégias de control da amoniémia, uso de técnicas extracorporais, e a prescrição de antibióticos profilácticos. Conclusões: A abordagem de doentes com ALF por profissionais da $\mathrm{UCl}$ diferiu substancialmente em aspectos clínicos importantes. Educação e investigação de qualidade adicionais serão necessárias.

๑) 2021 Sociedade Portuguesa de Gastrenterologia Publicado por S. Karger AG, Basel

\section{Introduction}

Acute liver failure (ALF) describes a new (no previous cirrhosis) and rapidly evolving ( $\leq 26$ weeks) liver dysfunction associated with neurologic dysfunction (hepatic encephalopathy $[\mathrm{HE}]$ ) and coagulopathy (international normalized ratio [INR] $\geq 1.5)[1-3]$. It is a rare disease with a hospital survival rate of about $60 \%$ [1]. This has been improving over the past decades due to earlier diagnosis, timely transfer to specialized centers, better management in the intensive care unit (ICU), and developments in emergency liver transplantation (ELT) $[1,2]$.

The clinical course of ALF depends on etiology, time from disease onset to the development of HE, and the timely diagnosis and treatment of ensuing organ failure $[3,4]$. ELT is the definitive treatment for patients with ALF when the potential to regenerate liver function and survival are predicted to be poor [5].

Reports on ALF epidemiology and outcomes have documented regional variability [6-8]. We hypothesized that the approach to ALF in different ICUs could vary substantially. We performed a survey to characterize the approach to ALF by ICU professionals. We aimed to identify points of care that could be improved, educational goals to be enforced, and research topics to be prioritized.

\section{Methods}

This study was endorsed by the European Society of Intensive Care Medicine (ESICM). Participation was voluntary and consent implied by its completion.

Acute Liver Failure Care
Study Design, Setting, and Participants

We performed a cross-sectional survey aimed at examining current practice on ALF by ICU professionals worldwide, including physicians and nurses. The survey was conducted between November 2018 and June 2019.

\section{Survey Development and Implementation}

The survey content was based on literature about ALF [9-12] and comprised questions (online supplementary file 1, for all suppl. material, see www.karger.com/doi/10.1159/000516672) on the demographics of ICU professionals (7 questions), the characterization of patients with ALF admitted to ICU (5 questions), and management of patients (13 questions). All questions were given specific options for answers, with 10 having possible multiple answers and 15 an optional free text response [13]. The survey was reviewed by authors and reviewers of the ESICM Research Committee. It underwent pilot-testing in the ICU at $\mathrm{CCH}$ to assess comprehension, feasibility, redundancy, and consistency [14].

The survey was created using a Web-based platform (SurveyMonkey ${ }^{\circledR}$ ) by ESICM staff and implemented and promoted via the ESICM website (https://www.esicm.org/research/surveys/\# ALFinICU). All respondents were ESICM website spontaneous visitors.

\section{Statistical Analysis}

Continuous and categorical variables were reported as median (interquartile range) and $n(\%)$, respectively. Missing data across all variables were $1.9 \%$, so no imputation was performed.

Univariate comparisons were performed using the MannWhitney U/Kruskal-Wallis test or $\chi^{2} /$ Fisher test where appropriate. Statistical significance was defined as $p<0.05$ (2-tailed). Statistical analysis was performed using SPSS v20 (IBM Corp., North Castle, NY, USA).

\section{Results}

\section{Demographics of Participants}

A total of 204 participants completed the survey in a median 7 (IQR 5-10) min. Median age was 42 (IQR 3550) years, with 140 (68.6\%) working in European countries (online suppl. file 2) and $146(71.6 \%)$ as certified intensivists (Table 1). Regarding the hospital setting, 160 (78.4\%) worked in tertiary care hospitals (51 [25.0\%] with ELT) and 167 (82.3\%) in medical and surgical ICUs (Table 1).

\section{Characteristics of Patients with ALF Admitted to the ICU}

Of the respondents, 142 (69.6\%) worked in ICUs admitting $<25$ patients with ALF per year, with 166 (81.8\%) reporting that $<25 \%$ of the cases were due to paracetamol toxicity (Table 2). The most frequent reasons for admitting patients with ALF to the ICU were: the need for organ support (89.2\%), West Haven criteria grade III-IV 
HE (73.5\%), a potential indication for ELT (33.8\%), or an INR $\geq 2(26.5 \%)$.

In total, $126(75.0 \%)$ reported that ELT was performed in $<25 \%$ of patients with ALF, with 142 (78.5\%) using the King's College Hospital criteria (KCC) for ELT listing. In terms of mortality, 140 (73.3\%) estimated a hospital mortality rate $<50 \%$ for their patients with ALF.

\section{Management of Patients with ALF in the ICU}

Eighty-eight (43.3\%) reported prescribing $\mathrm{N}$-acetylcysteine (NAC) for all etiologies of ALF (Table 2). As for the triggers used for endotracheal intubation (ETI), the most common were coma $(84.8 \%)$, respiratory failure (72.5\%), and grade III-IV HE (59.8\%).

In terms of monitoring the risk of cerebral edema, the most frequent indicators used were pupillary abnormalities (78.7\%), head computed tomography (CT; 69.8\%), or serum ammonia (53.5\%). Regarding serum ammonia, 117 (57.6\%) performed daily measurements.

Table 1. Demographics of 203 participants

$\begin{array}{lc}\text { Median age (IQR), years } & 42(35-50) \\ \text { Geographical location } & \\ \text { Europe } & 140(68.6) \\ \text { North America } & 5(2.5) \\ \text { South America } & 17(8.3) \\ \text { Asia } & 35(17.2) \\ \text { Africa } & 2(1.0) \\ \text { Australia and New Zealand } & 5(2.5) \\ \text { Level of training } & \\ \text { Fellow in Intensive Care Medicine } & 40(19.6) \\ \text { Fellow in other specialty } & 9(4.4) \\ \text { Intensivist } & 146(71.6) \\ \text { Other specialist } & 6(2.9) \\ \text { Nurse or other } & 3(1.5) \\ \text { Hospital type } & \\ \text { Secondary care } & 26(12.7) \\ \text { Tertiary care } & 109(53.4) \\ \text { Liver transplant center } & 51(25.0) \\ \text { Other } & 18(8.8) \\ \text { ICU type } & \\ \text { Medical } & 17(8.4) \\ \text { Surgical } & 19(9.4) \\ \text { Medical and surgical } & 167(82.3) \\ \text { ICU model } & \\ \text { Open } & 80(39.2) \\ \text { Closed } & 124(60.8) \\ \text { Number of ICU beds } & 33(16.3) \\ <10 & 95(46.8) \\ \text { 10-20 } & 75(36.9) \\ \geq 20 & \end{array}$

Values express $n(\%)$, unless otherwise indicated.
Concerning the treatment of cerebral edema, the most common interventions used were osmotic therapy (86.2\%), sedation (81.3\%), serum ammonia-lowering strategies $(75.4 \%)$, and vasopressors (68.5\%).

The most frequent serum ammonia-lowering strategies used were laxatives (86.2\%), continuous renal replacement therapy (CRRT; 57.1\%), or L-ornithine-L-aspartate (LOLA; 28.6\%). As for other extracorporeal devices, 83 (41.1\%) used plasma exchange and 59 (29.2\%) used liver-assist devices (e.g., Molecular Adsorbent Recirculating System).

The most common thresholds used for transfusing blood products were bleeding or invasive procedure (86.1\%), hemoglobin $<70 \mathrm{~g} / \mathrm{L}(81.4 \%)$, platelets $<50 \times 10^{9} /$ $\mu \mathrm{L}(20.8 \%)$, and fibrinogen $<1.5 \mathrm{~g} / \mathrm{L}(18.3 \%)$.

One hundred and twenty-six (61.8\%) used prophylactic antibiotics for ALF with specific triggers, namely, shock (41.7\%), progressive HE (28.9\%), and procalcito$\operatorname{nin}>2 \mathrm{ng} / \mathrm{mL}(22.1 \%)$.

Liver biopsy was reported to be requested by 135 (67.5\%) respondents, especially in cases of unknown etiology (57.0\%), for ELT listing (18.0\%), or for prognosis (16.0\%).

The most prevalent criteria regarding futility of care were refractory multiorgan failure $(86.1 \%)$, contraindication for ELT (51.5\%), or a history of substance abuse (e.g., alcohol; 31.7\%).

\section{Management of Patients with ALF in the ICU: Study of Associations}

The prescription of NAC for all etiologies of ALF was more frequent in respondents that admitted a higher number of patients with paracetamol toxicity (Table 3: $38.8 \%$ if $<25 \%$ admitted vs. $54.2 \%$ if $25-50 \%$ admitted vs.

Table 2 (Footnote)

Values are expressed as $n(\%)$. ALF, acute liver failure; ICU, intensive care unit; HE, hepatic encephalopathy (West Haven criteria); INR, international normalized ratio; ELT, emergency liver transplantation; KCC, King's College Hospital criteria; USALFSG, United States Acute Liver Failure Study Group; MELD, model end-stage liver disease; PELD, pediatric end-stage liver disease; PF, oxygen arterial partial pressure/ oxygen inspired fraction; $\mathrm{PaCO}_{2}$, carbon dioxide arterial partial pressure; CT, computed tomography; ONSD, optic-nerve sheath diameter; MAP, mean arterial pressure; LOLA, L-ornithine-L-aspartate; RRT, renal replacement therapy; MARS, Molecular Adsorbent Recirculating System; ROTEM, rotational thromboelastometry; TEG, thromboelastography. a $\mathrm{PF} \leq 300 \mathrm{~mm} \mathrm{Hg}$ or $\mathrm{PaCO}_{2}<30 \mathrm{~mm} \mathrm{Hg}$.
Cardoso/Mcphail/Karvellas/Fuhrmann/ Germano/Auzinger 
Table 2. Characteristics and management of patients with ALF admitted to ICU

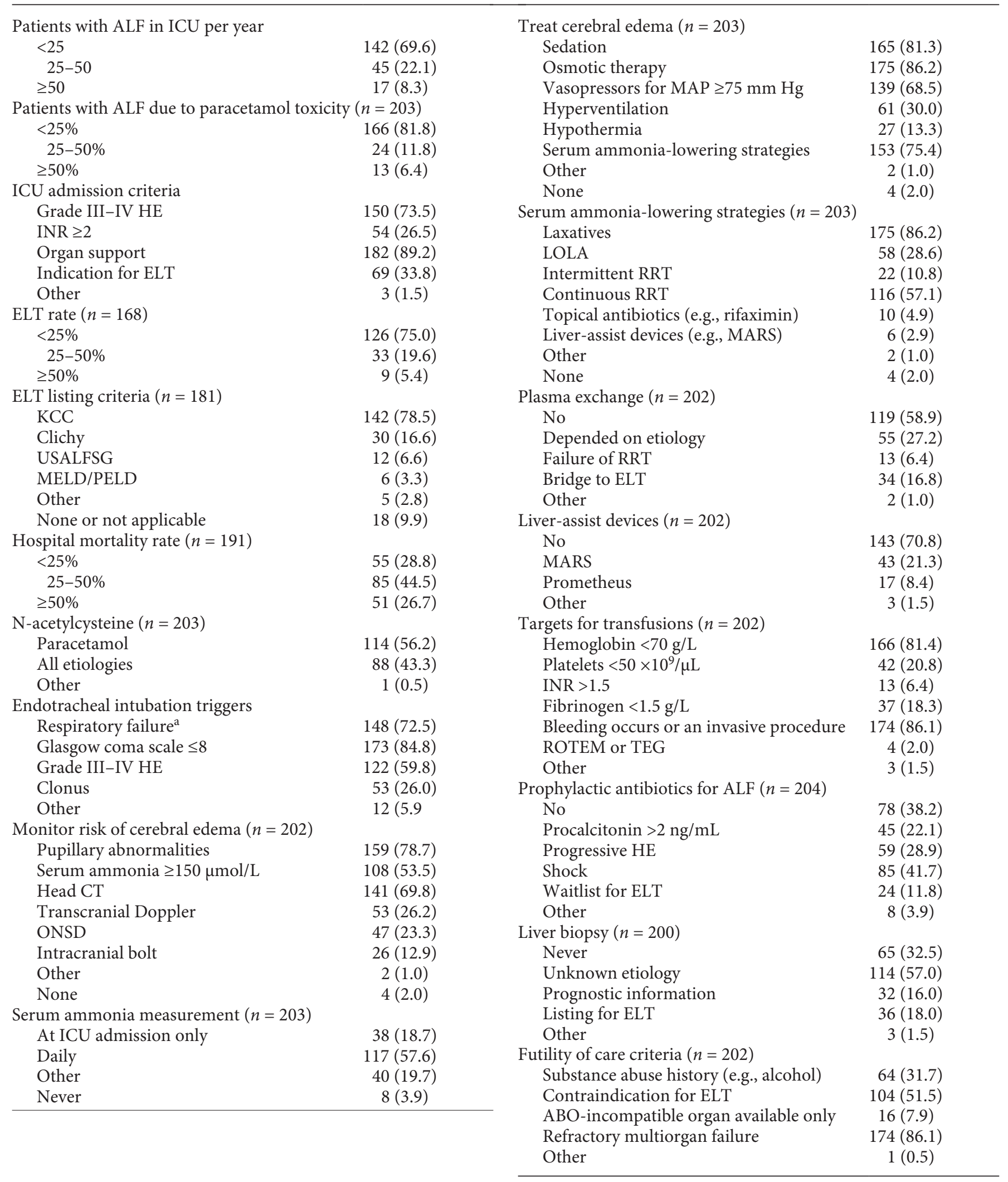


$76.9 \%$ if $\geq 50 \%$ admitted; $p=0.003$ ) and those working at ELT centers ( 58.8 vs. other $38.2 \%$; $p=0.033$ ).

ETI for grade III-IV HE was more common among fellows of intensive care medicine or intensivists (ICU 67.5 vs. other $33.3 \%$; intensivists 61.6 vs. other $22.2 \%$; $p=$ $0.040)$ and those working at ELT centers (74.5 vs. other $54.9 \% ; p=0.013$ ).

Daily serum ammonia measurements were more frequently performed by individuals from North America (Europe $62.6 \%$ vs. North America $80.0 \%$ vs. other $44.1 \%$; $p=0.008)$, those that admitted a lower number of patients with paracetamol toxicity $(59.4 \%$ if $<25 \%$ admitted vs. $45.8 \%$ if $25-50 \%$ admitted vs. $53.8 \%$ if $\geq 50 \%$ admitted; $p=0.017$ ), and those working at ELT centers (ELT center $74.5 \%$ vs. other $52.0 \% ; p=0.026$ ). The use of a serum ammonia level $\geq 150 \mu \mathrm{mol} / \mathrm{L}$ to monitor the risk of cerebral edema was more common among participants that admitted a higher number of patients with paracetamol toxicity (50.6\% if $<25 \%$ admitted vs. $50.0 \%$ if $25-50 \%$ admitted vs. $92.3 \%$ if $\geq 50 \%$ admitted; $p=0.014$ ) and those working at ELT centers (ELT center $66.7 \%$ vs. other $49.0 \%$; $p=0.029$ ).

The use of CRRT to decrease serum ammonia was more frequent among older respondents ( 44 vs. 39 years; $p=0.038$ ), those from North America (Europe $64.7 \%$ vs. North America $80.0 \%$ vs. other $37.3 \%$; $p=0.010$ ), those working at ELT centers (ELT center $78.4 \%$ vs. other $50.0 \% ; p<0.001$ ), and those that admitted a higher number of patients with paracetamol toxicity $(52.1 \%$ if $<25 \%$ admitted vs. $79.2 \%$ if $25-50 \%$ admitted vs. $84.5 \%$ if $\geq 50 \%$ admitted; $p=0.005$ ).

The use of plasma exchange (ELT center $58.8 \%$ vs. other $35.1 \%$; $p=0.003$ ) or liver-assist devices (ELT center $56.9 \%$ vs. other $19.9 \%$; $p<0.001$ ) was more common among individuals working at ELT centers.

The prescription of prophylactic antibiotics was more frequently made by those working in secondary care hospitals (secondary care $76.9 \%$ vs. tertiary care $61.5 \%$ vs. ELT center 64.7\%; $p=0.031$ ).

\section{Discussion}

Key Results and Comparisons with the Previous Literature

The majority of individuals admitted $<25$ patients with ALF per year $(69.6 \%)$ and $<25 \%$ had paracetamol toxicity (81.8\%). The incidence of ALF is $\leq 10$ cases per million people per year in developed countries, so only ELT centers within highly populated areas may treat a high volume of cases [4]. In the UK, North America, and Austra-
lia/New Zealand, paracetamol overdose has been the leading etiology of ALF $[1,2,15]$. In continental Europe, the most common causes of ALF have been nonparacetamol drug-induced liver injury, seronegative liver injury, and hepatitis $B[8,16,17]$. Consequently, ICU professionals outside the UK, North America, and Australia/ New Zealand $(>80.0 \%)$ are expected to deal mostly with non-paracetamol ALF.

Most of the respondents reported an ELT rate $<25 \%$ (75.0\%) and an in-hospital mortality rate $<50 \%(73.3 \%)$. As the majority admitted patients with non-paracetamol ALF, we would have expected a higher ELT rate. Although the decision to list patients with ALF for ELT is complex, clinicians have been relying more on prognostic systems, such as the KCC (78.5\%), to select patients for ELT. However, jurisdiction-specific legislation on organ donation may have influenced organ availability in different regions. Nevertheless, the in-hospital mortality rate reported by the majority of the participants was comparable to the literature $[1,8,16-19]$. This suggests that patients are being better managed with medical treatment alone.

A minority prescribed NAC for all etiologies of ALF (43.3\%); this was more frequent among ICU professionals working with a higher volume of patients with paracetamol toxicity or at ELT centers. NAC is the antidote for paracetamol toxicity via its action of replenishing glutathione, a crucial molecule for paracetamol detoxification in the liver [20]. However, NAC has also improved transplant-free survival in patients with non-paracetamol ALF [21]. This may be related to its improvement of hemodynamics and oxygen use or the decrease in the risk of cerebral edema [22, 23]. Therefore, current management of ALF should consider prescribing NAC for all etiologies of ALF [9, 10, 21, 24].

Around 59.8\% respondents intubated patients with ALF due to grade III-IV HE, with this being more common among intensive care fellows, intensivists, and ICU professionals from ELT centers. Patients with ALF may be at risk of developing cerebral edema due to astrocyte swelling, a complex process in which ammonia and lactate are involved [25]. ETI for grade III-IV HE is recommended to prevent aspiration and allow for the early treatment of cerebral edema $[11,12]$.

The majority of respondents monitored the risk of cerebral edema using pupillary abnormalities (78.7\%), head CT $(69.8 \%)$, or serum ammonia (53.5\%), with a minority using transcranial Doppler (TCD; 26.2\%), optic-nerve sheath diameter (ONSD; 23.3\%), or intracranial bolt (12.9\%). Frequent pupillary exam is mandatory to detect signs of intracranial hypertension. Moreover, these signs present often
Cardoso/Mcphail/Karvellas/Fuhrmann/ Germano/Auzinger 
Table 3. Management of ALF in the ICU: study of associations

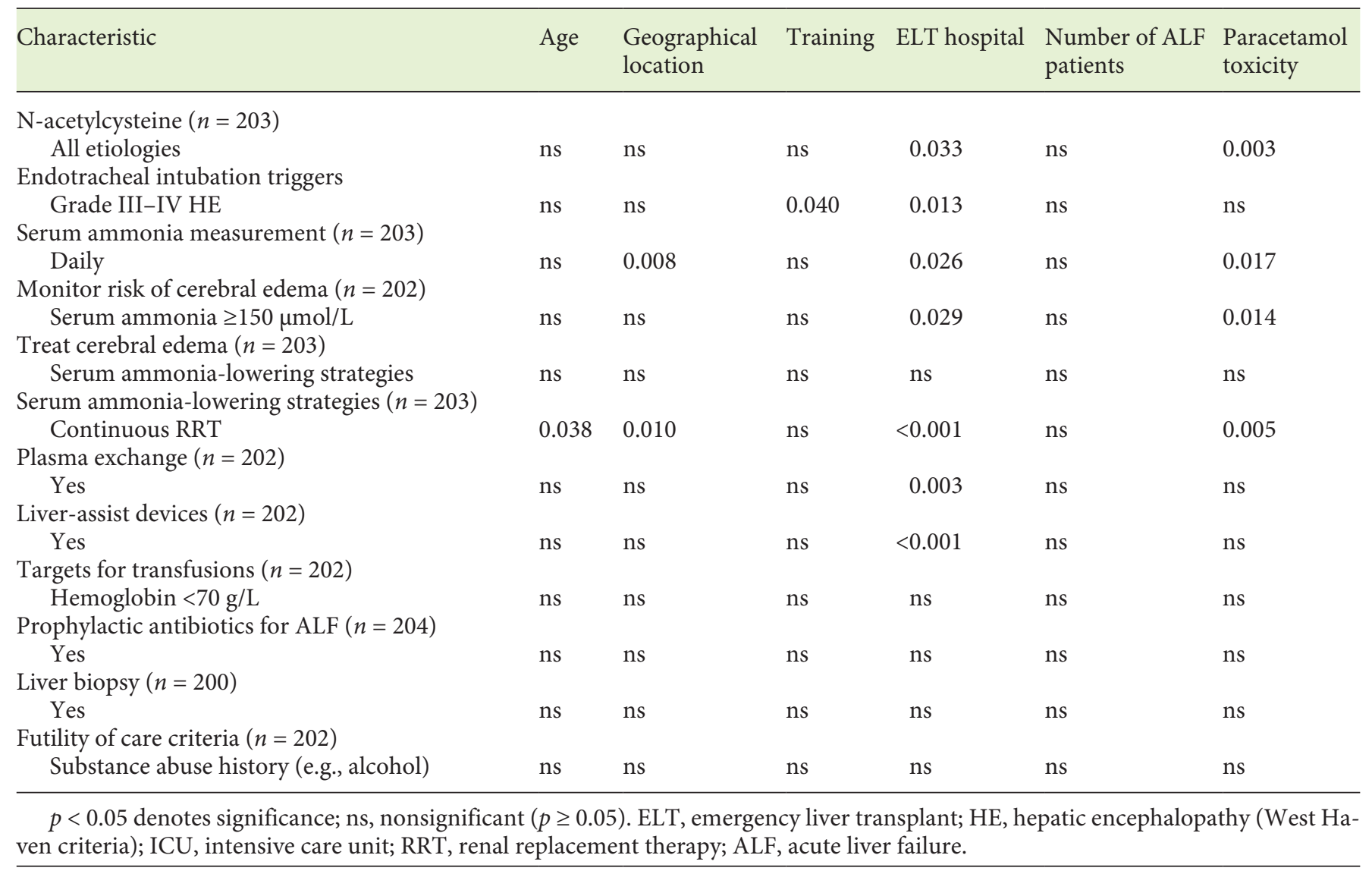

late on head CT. TCD or ONSD still lack validation in ALF [26]. Measurement of intracranial pressure with a bolt may be useful but its effect on patients' outcomes has been controversial [27]. Therefore, even if the prevalence of cerebral edema in ALF has been decreasing over the past decades, a coherent strategy to monitor the risk of intracranial hypertension (ICH) is still lacking [28].

Hyperammonemia $(\geq 150 \mu \mathrm{mol} / \mathrm{L})$ has been associated with an increased risk of ICH, so frequent measurement may help to prevent this [29]. However, only $57.6 \%$ of the respondents measured serum ammonia daily, this being more frequent among ICU professionals working with a higher volume of patients with paracetamol toxicity or at ELT centers. Frequent measurement of arterial blood ammonia should be further encouraged as a means to monitor the risk of developing neurological complications $[9,11]$.

To lower serum ammonia, the majority of the respondents administered laxatives (86.2\%) or CRRT (57.1\%). A minority used LOLA (28.6\%), intermittent renal replacement therapy (IRRT; $10.8 \%)$, topical antibiotics (4.9\%), or liver-assist devices (2.9\%). In ALF, while lactulose may reduce ammonia, time to effect is long and there is the added risk of bowel distention [30-34]. The case for LOLA or topical antibiotics still lacks evidence, and they are also frequently unavailable $[11,12,35]$. CRRT, more frequently used by older ICU professionals and those from North America, working at ELT centers, or admitting a higher volume of patients with paracetamol toxicity, has been shown to decrease serum ammonia and improve survival, effects that are lacking with IRRT [36].

Liver-assist devices were used by $29.2 \%$ of the respondents for ALF, this being more common among ICU professionals at ELT centers. In fact, the case for use of these devices still lacks evidence [37]. Plasma exchange for ALF was performed by $41.1 \%$ of all respondents, also mainly ICU professionals at ELT centers. While there is evidence to support the use of plasma exchange, the timing, dose, and interaction with ELT listing decisions remain uncertain [38].

Regarding the use of extracorporeal devices, CRRT should be the first option to treat metabolic imbalance and control hyperammonemia [36]. For patients with 
ALF progressing to multiorgan failure, especially with high-dose vasopressors or if ELT is not an option, plasma exchange may be considered [39].

The majority of respondents prescribed prophylactic antibiotics for ALF (61.8\%), with this being more common among ICU professionals from secondary care hospitals. In ALF, prophylactic antibiotics have not been found to improve survival [40]. However, the development of grade III-IV HE or systemic inflammatory response syndrome has been associated with infection and worse outcomes [41, 42]. Therefore, high clinical suspicion and frequent screening for sepsis remain fundamental to initiate antimicrobials $[11,12]$.

The majority of participants requested liver biopsy for patients with ALF (67.5\%). Often, liver biopsy does not provide information about etiology due to sample error, or else the extent of necrosis precludes a thorough evaluation. It may help to exclude cirrhosis, alcoholic hepatitis, or malignancy $[43,44]$. Furthermore, submassive or massive patterns of necrosis have been associated with a lower likelihood of liver function regeneration [45]. Therefore, liver biopsy remains a controversial intervention in ALF.

The majority of respondents considered refractory multiorgan failure $(86.1 \%)$ or contraindication for liver transplant (51.5\%) as criteria for futility of care. A small number also accepted substance abuse history (31.7\%) or $\mathrm{ABO}$-incompatible organ availability (7.9\%). It seems reasonable that patients with ALF and multiorgan failure unresponsive to treatment may be considered for end-oflife discussions. Deciding contraindications for ELT is often complex. Psychosocial factors such as mental health, substance dependence, or presumed compliance with treatment are difficult to assess in an acute context. Therefore, comprehensive case-specific discussion within a multidisciplinary team is likely the best course of action [11]. Regarding ABO-incompatible ELT, these patients can show worse outcomes, but this intervention may, at times, be their only chance of survival $[46,47]$. Overall, decisions about futility of care in ALF still lack evidence.

\section{Limitations}

Our study has the following limitations that warrant consideration. Firstly, while our survey underwent pilot testing, this was a novel online instrument of research in ALF. Secondly, as it was implemented via the ESICM website, this may have contributed to selection bias, as ESICM members or frequent online visitors were more likely to respond to it. Thirdly, the survey relied on answers from individuals, which may have led to recall bias or other types of response bias. Despite these limitations, we consider that our findings may help to identify pointsof-care reflected in recent guidelines that may benefit from further education and research activities [11, 12]. Although many diagnostic and therapeutic interventions in ALF still lack high-quality evidence, professionals from ELT centers seem to have implemented more of such recommend interventions. Cross-collaboration between referral and ELT centers may therefore continue to be one way to enforce better management of patients with ALF.

\section{Conclusions}

The management of patients with ALF by ICU professionals varies with age, region, level of training, type of hospital, and the number of patients with each etiology admitted. Further education and high-quality research can improve the delivery of care in the ICU.

\section{Acknowledgments}

Thank you to Sherihane Bensemmane from ESICM for the technical support. Thank you to ESICM, especially the Metabolism, Endocrinology, and Nutrition Section, and the Liver Failure Group of the Portuguese Intensive Care Society for the institutional support.

\section{Statement of Ethics}

This study protocol was approved by the ethics committee at Curry Cabral Hospital (CCH), Central Lisbon University Hospital Center (CLUHC), Lisbon, Portugal (464/2017). Informed consent was implied in the participants responses to the survey. This study abided by the principles of the Declaration of Helsinki and Strobe statement.

\section{Conflict of Interest Statement}

The authors have no conflicts of interest to declare.

\section{Funding Source}

The authors have no funding sources to declare.

\section{Author Contributions}

All authors contributed to the study conception. Design, material preparation, data collection, and analysis were performed by F.S.C. The first draft of the manuscript was written by F.S.C. All authors read and approved the final version.
Cardoso/Mcphail/Karvellas/Fuhrmann/ Germano/Auzinger 
1 Bernal W, Hyyrylainen A, Gera A, Audimoolam VK, McPhail MJ, Auzinger G, et al. Lessons from look-back in acute liver failure? A single centre experience of 3300 patients. J Hepatol. 2013 Jul;59(1):74-80.

2 Ostapowicz G, Fontana RJ, Schiødt FV, Larson A, Davern TJ, Han SH, et al.; U.S. Acute Liver Failure Study Group. Results of a prospective study of acute liver failure at 17 tertiary care centers in the United States. Ann Intern Med. 2002 Dec;137(12):94754.

3 O'Grady JG, Schalm SW, Williams R. Acute liver failure: redefining the syndromes. Lancet. 1993 Jul;342(8866):273-5.

4 Bernal W, Wendon J. Acute liver failure. N Engl J Med. 2013 Dec;369(26):2525-34.

5 Gulmez SE, Larrey D, Pageaux GP, Bernuau J, Bissoli F, Horsmans Y, et al. Liver transplant associated with paracetamol overdose: results from the seven-country SALT study. Br J Clin Pharmacol. 2015 Sep;80(3):599-606.

6 Acharya SK, Batra Y, Hazari S, Choudhury V, Panda SK, Dattagupta S. Etiopathogenesis of acute hepatic failure: eastern versus Western countries. J Gastroenterol Hepatol. 2002 Dec;17 Suppl 3:S268-73.

7 Hadem J, Tacke F, Bruns T, Langgartner J, Strnad P, Denk GU, et al.; Acute Liver Failure Study Group Germany. Etiologies and outcomes of acute liver failure in Germany. Clin Gastroenterol Hepatol. 2012 Jun;10(6):6649.e2.

8 Simões C, Santos S, Vicente M, Sousa Cardoso F. Epidemiology of Acute Liver Failure from a Regional Liver Transplant Center in Portugal. GE Port J Gastroenterol. 2018 Dec;26(1):33-9.

9 Cardoso FS, Marcelino P, Bagulho L, Karvellas CJ. Acute liver failure: an up-to-date approach. J Crit Care. 2017 Jun;39:25-30.

10 Fix OK, Liou I, Karvellas CJ, Ganger DR, Forde KA, Subramanian RM, et al.; Acute Liver Failure Study Group. Development and Pilot of a Checklist for Management of Acute Liver Failure in the Intensive Care Unit. PLoS One. 2016 May;11(5):e0155500.

11 Wendon J, Cordoba J, Dhawan A, Larsen FS, Manns M, Samuel D, et al.; EASL Governing Board representative. EASL Clinical Practical Guidelines on the management of acute (fulminant) liver failure. J Hepatol. 2017 May;66(5):1047-81.

12 Polson J, Lee WM; American Association for the Study of Liver Disease. AASLD position paper: the management of acute liver failure. Hepatology. 2005 May;41(5):1179-97.

13 Gehlbach H, Artino AR Jr. The Survey Checklist (Manifesto). Acad Med. 2018 Mar;93(3):360-6.

14 Duffett M, Burns KE, Adhikari NK, Arnold DM, Lauzier F, Kho ME, et al. Quality of reporting of surveys in critical care journals: a methodologic review. Crit Care Med. 2012 Feb;40(2):441-9.
15 Hey P, Hanrahan TP, Sinclair M, Testro AG, Angus PW, Peterson A, et al. Epidemiology and outcomes of acute liver failure in Australia. World J Hepatol. 2019 Jul;11(7):58695.

16 Rabinowich L, Wendon J, Bernal W, Shibolet O. Clinical management of acute liver failure: results of an international multi-center survey. World J Gastroenterol. 2016 Sep;22(33):7595-603.

17 Escorsell A, Mas A, de la Mata M; Spanish Group for the Study of Acute Liver Failure. Acute liver failure in Spain: analysis of 267 cases. Liver Transpl. 2007 Oct;13(10):138995.

18 Fontana RJ, Ellerbe C, Durkalski VE, Rangnekar A, Reddy RK, Stravitz T, et al.; US Acute Liver Failure Study Group. Two-year outcomes in initial survivors with acute liver failure: results from a prospective, multicentre study. Liver Int. 2015 Feb;35(2):370-80.

19 Warrillow S, Bailey M, Pilcher D, Kazemi A, McArthur C, Young P, et al. Characteristics and outcomes of patients with acute liver failure admitted to Australian and New Zealand intensive care units. Intern Med J. 2019 Jul;49(7):874-85.

20 Heard KJ. Acetylcysteine for acetaminophen poisoning. N Engl J Med. 2008 Jul;359(3):28592.

21 Lee WM, Hynan LS, Rossaro L, Fontana RJ, Stravitz RT, Larson AM, et al.; Acute Liver Failure Study Group. Intravenous N-acetylcysteine improves transplant-free survival in early-stage non-acetaminophen acute liver failure. Gastroenterology. 2009 Sep;137(3): 856-64.

22 Harrison PM, Wendon JA, Gimson AE, Alexander GJ, Williams R. Improvement by acetylcysteine of hemodynamics and oxygen transport in fulminant hepatic failure. N Engl J Med. 1991 Jun;324(26):1852-7.

23 Stravitz RT, Sanyal AJ, Reisch J, Bajaj JS, Mirshahi F, Cheng J, et al.; Acute Liver Failure Study Group. Effects of N-acetylcysteine on cytokines in non-acetaminophen acute liver failure: potential mechanism of improvement in transplant-free survival. Liver Int. 2013 Oct;33(9):1324-31.

24 Squires RH, Dhawan A, Alonso E, Narkewicz MR, Shneider BL, Rodriguez-Baez N, et al.; Pediatric Acute Liver Failure Study Group. Intravenous $\mathrm{N}$-acetylcysteine in pediatric patients with nonacetaminophen acute liver failure: a placebo-controlled clinical trial. Hepatology. 2013 Apr;57(4):1542-9.

25 Butterworth RF. Pathogenesis of hepatic encephalopathy and brain edema in acute liver failure. J Clin Exp Hepatol. 2015 Mar;5 Suppl 1:S96-103.

26 Rajajee V, Williamson CA, Fontana RJ, Courey AJ, Patil PG. Noninvasive Intracranial Pressure Assessment in Acute Liver Failure. Neurocrit Care.2018Oct;29(2):28090.
27 Karvellas CJ, Fix OK, Battenhouse H, Durkalski V, Sanders C, Lee WM; U S Acute Liver Failure Study Group. Outcomes and complications of intracranial pressure monitoring in acute liver failure: a retrospective cohort study. Crit Care Med. 2014 May;42(5):1157-67.

28 Bernal W, Lee WM, Wendon J, Larsen FS, Williams R. Acute liver failure: A curable disease by 2024? J Hepatol. 2015 Apr;62(1 Suppl):S112-20.

29 Bernal W, Hall C, Karvellas CJ, Auzinger G, Sizer E, Wendon J. Arterial ammonia and clinical risk factors for encephalopathy and intracranial hypertension in acute liver failure. Hepatology. 2007 Dec;46(6):1844-52.

30 Bernal W, Murphy N, Brown S, Whitehouse T, Bjerring PN, Hauerberg J, et al. A multicentre randomized controlled trial of moderate hypothermia to prevent intracranial hypertension in acute liver failure. J Hepatol. 2016 Aug;65(2):273-9.

31 Murphy N, Auzinger G, Bernel W, Wendon J. The effect of hypertonic sodium chloride on intracranial pressure in patients with acute liver failure. Hepatology. 2004 Feb;39(2):46470.

32 Canalese J, Gimson AE, Davis C, Mellon PJ, Davis M, Williams R. Controlled trial of dexamethasone and mannitol for the cerebral oedema of fulminant hepatic failure. Gut. 1982 Jul;23(7):625-9.

33 Ede RJ, Gimson AE, Bihari D, Williams R. Controlled hyperventilation in the prevention of cerebral oedema in fulminant hepatic failure. J Hepatol. 1986;2(1):43-51.

34 Alba L, Hay JE, Angulo P, Lee WM. Lactulose therapy in acute liver failure. J Hepatol. 2002;36:33A.

35 Acharya SK, Bhatia V, Sreenivas V, Khanal S, Panda SK. Efficacy of L-ornithine L-aspartate in acute liver failure: a double-blind, randomized, placebo-controlled study. Gastroenterology. 2009 Jun;136(7):2159-68.

36 Cardoso FS, Gottfried M, Tujios S, Olson JC, Karvellas CJ; US Acute Liver Failure Study Group. Continuous renal replacement therapy is associated with reduced serum ammonia levels and mortality in acute liver failure. Hepatology. 2018 Feb;67(2):711-20.

37 Saliba F, Camus C, Durand F, Mathurin P, Letierce A, Delafosse B, et al. Albumin dialysis with a noncell artificial liver support device in patients with acute liver failure: a randomized, controlled trial. Ann Intern Med. 2013 Oct;159(8):522-31.

38 Karvellas CJ, Subramanian RM. Current evidence for extracorporeal liver support systems in acute liver failure and acute-onchronic liver failure. Crit Care Clin. 2016 Jul;32(3):439-51.

39 Larsen FS, Schmidt LE, Bernsmeier C, Rasmussen A, Isoniemi H, Patel VC, et al. Highvolume plasma exchange in patients with acute liver failure: an open randomised controlled trial. J Hepatol. 2016 Jan;64(1):69-78. 
40 Karvellas CJ, Cavazos J, Battenhouse H, Durkalski V, Balko J, Sanders C, et al.; US Acute Liver Failure Study Group. Effects of antimicrobial prophylaxis and blood stream infections in patients with acute liver failure: a retrospective cohort study. Clin Gastroenterol Hepatol. 2014 Nov;12(11):1942-9.e1.

41 Vaquero J, Polson J, Chung C, Helenowski I, Schiodt FV, Reisch J, et al. Infection and the progression of hepatic encephalopathy in acute liver failure. Gastroenterology. 2003 Sep;125(3):755-64.

42 Rolando N, Wade J, Davalos M, Wendon J, Philpott-Howard J, Williams R. The systemic inflammatory response syndrome in acute liver failure. Hepatology. 2000 Oct;32(4 Pt 1):734-9.
43 Dechêne A, Sowa JP, Schlattjan M, Wree A, Blomeyer S, Best J, et al. Mini-laparoscopy guided liver biopsy increases diagnostic accuracy in acute liver failure. Digestion. 2014;90(4):240-7.

44 Donaldson BW, Gopinath R, Wanless IR, Phillips MJ, Cameron R, Roberts EA, et al. The role of transjugular liver biopsy in fulminant liver failure: relation to other prognostic indicators. Hepatology. 1993 Dec;18(6): 1370-6.
45 Ndekwe P, Ghabril MS, Zang Y, Mann SA, Cummings OW, Lin J. Substantial hepatic necrosis is prognostic in fulminant liver failure. World J Gastroenterol. 2017 Jun;23(23):430310.

46 Bernal W, Cross TJ, Auzinger G, Sizer E, Heneghan MA, Bowles M, et al. Outcome after wait-listing for emergency liver transplantation in acute liver failure: a single centre experience. J Hepatol. 2009 Feb;50(2):306-13.

47 Germani G, Theocharidou E, Adam R, Karam $\mathrm{V}$, Wendon J, O'Grady J, et al. Liver transplantation for acute liver failure in Europe: outcomes over 20 years from the ELTR database. J Hepatol. 2012 Aug;57(2):288-96. 